\title{
Synthesis and Impregnation of Copper Oxide Nanoparticles on Activated Carbon through Green Synthesis for Water Pollutant Removal
}

\author{
Josiane Peternela ${ }^{a}$, Marcela Fernandes Silva ${ }^{a}$, Marcelo Fernandes Vieira ${ }^{a}$, Rosângela Bergamasco ${ }^{a}$, \\ Angélica Marquetotti Salcedo Vieira ${ }^{\text {** }}$ \\ ${ }^{a}$ Departamento de Engenharia Química, Universidade Estadual de Maringá, Maringá, PR, Brazil \\ ${ }^{b}$ Departamento de Engenharia de Alimentos, Universidade Estadual de Maringá, Av. Colombo, 5790, \\ CEP 87020900, Maringá, PR, Brazil
}

Received: June 16, 2016; Revised: September 24, 2017; Accepted: November 10, 2017

In this article was developed a green synthesis of $\mathrm{CuO}$ nanoparticles on vegetal activated carbon (VAC), using pomegranate leaf extract as reducing and stabilizing agent in the removal of multiple pollutants. The impregnated carbons with $\mathrm{CuO}$ nanoparticles were characterized morphologically and structurally. The SEM and XRD analysis, after carbons modification, showed that the surface structure remained porous with $\mathrm{CuO}$ nanoparticles sizes between 40 and $78 \mathrm{~nm}$. As concern to the contaminants atrazine, caffeine and diclofenac, it is observed that the maximum adsorption capacities practically did not suffer interference by the presence of $1.5 \% \mathrm{Cu}$ nanoparticles, keeping their values very close to those obtained with pure carbon. The nitrate removal was favored by the impregnation of $\mathrm{CuO}$ nanoparticles, from $0.93 \mathrm{mg} \mathrm{g}^{-1}$ to $4.09 \mathrm{mg} \mathrm{g}^{-1}$. The results are promising and demonstrate that it is possible to obtain VAC impregnated whit nanoparticles of $\mathrm{CuO}$ by a non-polluting and low cost method.

Keywords: Nanostructure, Microporous materials, Green synthesis, Adsorption.

\section{Introduction}

The nanotechnology development in conjunction with biotechnology has significantly expanded the nanomaterials application in several fields, such as medicine, electronics, wastewater treatment, water purification, food processing, industrial and household purposes, among others ${ }^{1}$. Copper oxides nanoparticles are technologically interesting due to their physical and chemical properties, and they can be applied in high temperature superconductors, catalysis, batteries, gas sensors, solar energy conversion ${ }^{2}$, or even as an antibacterial agent with low cost and low toxicity ${ }^{3}$.

There are several methods for copper nanoparticle synthesis. However, some limitations and disadvantages are presented in conventional methods, such as use of special equipment or high energy, resulting in high cost. The chemical substances involved in these processes are toxic, corrosive and flammable and they can cause several environmental damages ${ }^{4}$. A simple and viable alternative to chemical and physical methods is the green synthesis of nanoparticles ${ }^{5}$.

Amongst various natural materials used for nanoparticle obtainment, plants seem to be the best candidates because the nanoparticles produced using plants compounds are more stable and the production rate is fast ${ }^{6}$. Among these plants, pomegranate (Punica granatum) can be mentioned, which has been successfully used in the green synthesis of silver ${ }^{7}$, iron oxide ${ }^{8}$ and gold nanoparticles ${ }^{9}$. Due to its excellent antioxidant properties, with high polyphenols

*e-mail: amsvieira@uem.br concentrations, pomegranate becomes an interesting option of reducing agent in the process of obtaining nanoparticles ${ }^{10}$.

Several studies relate nanoparticles with other materials, such as activated carbon, silica, graphene, using them as support ${ }^{11-15}$. The activated carbon is known as an effective adsorbent because of its high surface area, well-developed internal pores structures and high surface reactivity ${ }^{16}$. Although the structural properties of activated carbon are effective at adsorption capacity, specific interactions of adsorbate/ adsorbent play an important role in the adsorption process. Improvements in the activated carbon properties can be obtained by impregnating metals over its surface, from copper, iron, chromium and zinc salts ${ }^{17}$. A large amount of research mentioned pesticides, drugs and nitrate as important pollutants that can be removed by this adsorbent ${ }^{18-22}$.

Nitrogen compounds, drugs and pesticides have been frequently detected in the aquatic environment ${ }^{23,24}$. Among these detected pesticides, atrazine causes serious risks for the environment and public healt ${ }^{25}$, since the pesticide has endocrine disruption reported in animals ${ }^{26-29}$ and it can be linked to cancer in humans $\mathrm{s}^{30,31}$. In addition to pesticides, other compounds that have been detected in wastewater and surface water around the world are caffeine and diclofenac ${ }^{32,33}$. Caffeine can cause several physiological effects such as stimulating the central nervous system, gastric acid secretion and diuresis. It has also been associated with certain disorders, including heart disease, carcinogenesis, renal failure and asthma ${ }^{34}$. The continuous diclofenac intake by human being has several 
biochemical adverse effects, such as cytotoxicity in liver and kidneys, and renal injury even at a concentration $1 \mu \mathrm{g}$ $\mathrm{L}^{-135}$. In turn, nitrate in drinking water has been linked to infectious diseases outbreaks ${ }^{36}$. Nitrate excess in drinking water can cause congenital problems in newborns and it is directly related to the Blue Baby Syndrome ${ }^{37}$.

It is usually found in literature studies with materials that remove one or two of these contaminants ${ }^{22,38-41}$. However, considering that it is common to find several contamination forms in drinking water and not just one, studying a material with multi-pollutant removal potential is extremely valuable, since it could make the water treatment process simpler and more cost-effective $e^{42-44}$.

Therefore, the aim of this study was to develop a green method of copper oxide nanoparticles impregnation on vegetal activated carbon, using pomegranate leaf extract, and to evaluate its action in removing multiple pollutants often found in drinking water.

\section{Materials and Methods}

\subsection{Synthesis and impregnation of nanoparticles}

Wang et al. ${ }^{4}$ adapted methodology was used for the synthesis and impregnation of the copper oxide nanoparticles. It was used coconut activated carbon as nanoparticles support. The pomegranate leaf extract was prepared by boiling $60 \mathrm{~g}$ fresh leaves in $1000 \mathrm{~mL}$ deionized water at $80{ }^{\circ} \mathrm{C}$ for $1 \mathrm{~h}$. After this period, the mixture was cooled at approximately $25^{\circ} \mathrm{C}$ and filtered for its immediate use. Copper sulfate was used to obtain a $\mathrm{Cu}$ concentration of $0.5 \%, 1 \%$ and $1.5 \%$ in relation to carbon mass. Pomegranate leaf extract and copper sulfate aqueous solutions were added in a ratio of $2: 1(\mathrm{v} / \mathrm{v})$ to the coconut activated carbon $(40 \mathrm{~g})$. The mixture was stirred at $160 \mathrm{rpm}$ in a shaking incubator (TE-421, Tecnal, Brazil) at $25^{\circ} \mathrm{C}$ for 12,24 and $36 \mathrm{~h}$. The samples were filtered and the carbon dried in a hot air oven (SXCR/42, Sterilifer, Brazil) at $50{ }^{\circ} \mathrm{C}$ until the complete solid mass stabilization obtained, thereby obtaining nine adsorbents which were named according to Table 1 .

Table 1. Impregnated carbons denomination.

\begin{tabular}{cc}
\hline Sample & Preparation conditions \\
\hline 1 & $0.5 \% \mathrm{Cu}-12 \mathrm{~h}$ \\
2 & $1 \% \mathrm{Cu}-12 \mathrm{~h}$ \\
3 & $1.5 \% \mathrm{Cu}-12 \mathrm{~h}$ \\
4 & $0.5 \% \mathrm{Cu}-24 \mathrm{~h}$ \\
5 & $1 \% \mathrm{Cu}-24 \mathrm{~h}$ \\
6 & $1.5 \% \mathrm{Cu}-24 \mathrm{~h}$ \\
7 & $0.5 \% \mathrm{Cu}-36 \mathrm{~h}$ \\
8 & $1 \% \mathrm{Cu}-36 \mathrm{~h}$ \\
9 & $1.5 \% \mathrm{Cu}-36 \mathrm{~h}$ \\
\hline
\end{tabular}

\subsection{Characterization of impregnated carbons}

Characterization of the as-prepared materials was carried out by different techniques. Morphological characteristics were analyzed using a scanning electron microscopy (SEM) coupled with energy dispersive spectrometer (EDS) (SS-550 Superscan, Shimadzu, Japan) and a transmission electron microscopy (TEM) (JEM-1400, JEOL, Japan). X-ray diffraction (XRD) patterns of samples were recorded with a Bruker-AXS D8 Advance analytical X-ray diffractometer using $\mathrm{CuK} \alpha$ radiation $(\lambda=1.5406 \AA)$. The total reflection $\mathrm{X}$-ray fluorescence (TXRF) spectrometry was used for elementary analyses in carbon samples. TXRF measurements were carried out by means of a TXRF spectrometer model S2 Picofox ${ }^{\mathrm{TM}}$ (Bruker, Germany) with an air-cooled X-ray tube and a Mo target was used. The TXRF spectra of the samples were recorded using a $600 \mathrm{~s}$ acquisition time and processed by the Spectra software, according to an internal standard-based analytical method.

The impregnation efficiency was calculated according to equation (1). The amount of copper present on the activated carbon surface $\left(\mathrm{Cu}_{\text {impregnated }}\right)$ was verified by the TXRF analysis, and the amount of copper loaded $\left(\mathrm{Cu}_{\text {loaded }}\right)$ in the impregnation solution was determinate according to item 2.1.

$$
\eta=\frac{C u_{\text {impregnated }}}{C u_{\text {loaded }}} \cdot 100
$$

Brunauer-Emmet-Teller (BET) surface area analysis of samples was performed using a Quantachrome NOVA 1000 series by $\mathrm{N}_{2}$ adsorption-desorption isotherms at $77 \mathrm{~K}$. The micropore volume and area was calculated by HorvathKawazoe (HK) method and t-plot method, respectively ${ }^{45-47}$.

The diameters (D) of copper oxide nanoparticles were estimated using Scherrer equation (2) from the most intense diffraction peaks related to copper compounds in XRD.

$$
D=K \lambda / \beta \cos \theta
$$

Where:

$\mathrm{D}$ is the average particles diameter. $\mathrm{K}$ is the Scherrer constant that depends on the particle shape (in this case, $0.89) ; \lambda$ is the electromagnetic radiation wavelength $(\mathrm{Cu}-\mathrm{K} \alpha$ radiation, $\lambda=1.54056 \AA) ; \theta$ is the diffraction angle and $\beta$ is the full width half-maximum of the diffraction peak (FWHM).

The point of zero charge (PZC) of carbon was determined using the method known as "experiment of 11 points". The procedure consisted of mixing $50 \mathrm{mg}$ of the samples with 50 $\mathrm{ml}$ of deionized water under different $\mathrm{pHs}$, ranging from 1 to 12 , using sodium hydroxide and hydrochloric acid solutions, both with $0.1 \mathrm{M}$ and $1 \mathrm{M}$, for the adjustment. Then, the mixture was stirred at $180 \mathrm{rpm}, 25^{\circ} \mathrm{C}$, for $24 \mathrm{~h}$. The $\mathrm{pH}$ was measured and recorded as final $\mathrm{pH}$. The difference between initial and final $\mathrm{pH}(\Delta \mathrm{pH})$ was plotted in relation to initial 
$\mathrm{pH}$ and the zero charge point was verified where the curve intersected the $\mathrm{X}$ axis ${ }^{48,49}$.

\subsection{Adsorption experiments}

To evaluate the adsorption capacity of the impregnated carbons, the following compounds were used as pollutants: atrazine pesticide, diclofenac, caffeine and nitrate.

Gupta et al. ${ }^{19}$ adapted methodology was used for atrazine removal assays. Batch experiments were performed in shaking incubator with agitation of $150 \mathrm{rpm}, 25^{\circ} \mathrm{C}$ for $4 \mathrm{~h}$, using 25 $\mathrm{mL}$ of commercial atrazine $(500 \mathrm{SC}$, Nortox, Brazil) aqueous solution ( $\left.5 \mathrm{mg} \mathrm{L}^{-1}\right), \mathrm{pH} 7$, and $0.1 \mathrm{~g}$ of adsorbent. At the end of this period, the solutions were filtered and analyzed by a HPLC system (Gilson, USA) controlled by Born software, equipped with manual injector Rheodyne, with injection volume of $20 \mu \mathrm{L}$, pump Model 307, UV/visible model 151 detector set to $220 \mathrm{~nm}$. The analysis was conducted using acetonitrile/water with ratio $(65 / 35 \mathrm{v} / \mathrm{v})$ as mobile phase and Microsorb-MV Column ( $5 \mu \mathrm{m}, 100 \AA$; 4,6申-250 mm)

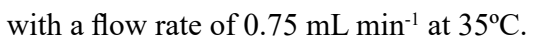

Caffeine and diclofenac removal testing used Torrellas et al. ${ }^{33}$ methodology. Batch experiments were performed in shaking incubator with stirring $(200 \mathrm{rpm})$ at $30^{\circ} \mathrm{C}$, for 6 $\mathrm{h}$, using $50 \mathrm{~mL}$ of potassium diclofenac or caffeine (Natural Pharma, Brazil) solution at $100 \mathrm{mg} \mathrm{L}^{-1}, \mathrm{pH} 7$ and $0.12 \mathrm{~g}$ of adsorbent. At the end of this period, the samples were filtered and analyzed by UV-Vis spectrophotometer (DR 5000, $\mathrm{HACH}$ ) at $274 \mathrm{~nm}$ for caffeine and $276 \mathrm{~nm}$ for diclofenac.

Öztürk and Bektaş ${ }^{36}$ methodology was used for nitrate adsorption testing. Batch experiments were carried out in shaking incubator with $140 \mathrm{rpm}$ stirring at $25^{\circ} \mathrm{C}$, for $3 \mathrm{~h}$, using $25 \mathrm{~mL}$ of sodium nitrate (Anidrol, Brazil) solution at $100 \mathrm{mg} \mathrm{L}^{-1}, \mathrm{pH} 7$, and $0.25 \mathrm{~g}$ of adsorbent. At the end of this period, the samples were filtered and analyzed by UV-Vis spectrophotometer at $205 \mathrm{~nm}$.

The adsorption capacity in equilibrium of the adsorbents was calculated by mass balance equation, equation (3), considering that the amount of adsorbate on the adsorbent is equal to the amount of adsorbate removed from the solution, mathematically:

$$
q_{e}=V\left(C_{o}-C_{e}\right) / m
$$

Where $\mathrm{q}_{\mathrm{e}}$ : adsorption capacity at equilibrium $\left(\mathrm{mg} \mathrm{g}^{-1}\right)$, $\mathrm{C}_{0}$ : initial adsorbate concentration in solution $\left(\mathrm{mg} \mathrm{L}^{-1}\right)$, $\mathrm{C}_{\mathrm{e}}$ : equilibrium concentration of adsorbate in solution ( $\left.\mathrm{mg} \mathrm{L}^{-1}\right), \mathrm{m}$ : adsorbent weight ( $\left.\mathrm{g}\right), \mathrm{V}$ : volume of aqueous solution (L).

The experiments were performed in duplicate and the results are presented as the mean \pm standard deviation.

\section{Results and Discussion}

\subsection{Adsorbents characterization}

The XRD pattern of pure and copper impregnated carbons is presented in Figure 1. The graph is plotted between $2 \theta=$ $15^{\circ}$ to $65^{\circ}$ and it shows the crystalline peaks found on the carbon amorphous matrix.

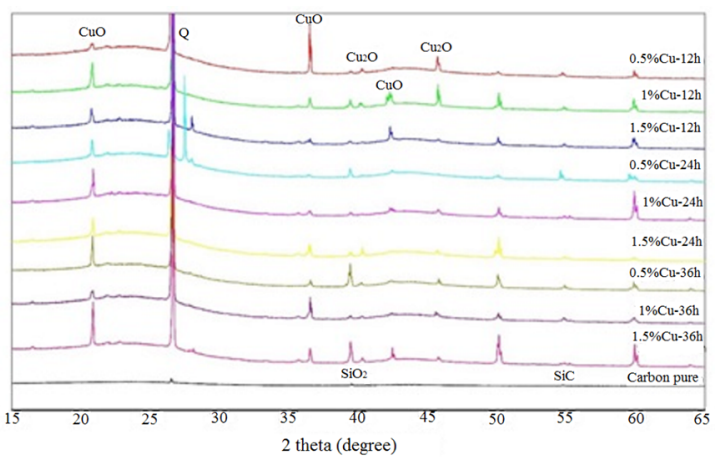

Figure 1. XRD pattern of pure and copper nanoparticles impregnated carbons at different concentrations and for different contact times.

Figure 1 shows pure carbon curve is apparently linear comparing to the other samples, due to the crystalline peaks intensity that emerged with copper impregnation. A halo located around $25^{\circ}$ was found in the samples, which is typical of amorphous carbon ${ }^{50}$. In some cases, it almost disappears completely with metal impregnation in activated carbon, due to the strength signal of the new compounds ${ }^{51,52}$. The peak observed at $2 \theta \cong 27^{\circ}$ is derived from an interference caused by quartz sample holder used in the XRD equipment. Foletto et al. ${ }^{53}$ also reported the existence of this signal in the sodium silicate crystalline spectrum. In addition, the peaks located at $2 \theta \cong 39.7^{\circ}$ and $54.6^{\circ}$ are derived from silicon dioxide and silicon carbide, respectively (JCPDS 18-1170 and JCPDS 22-1301), since the silicon is one of natural components present in vegetal carbon.

Using the available MDI Jade 5 XRD software database, peaks related to copper compounds were found in the impregnated carbon samples. Copper (II) oxide $(\mathrm{CuO})$ was detected in 2 theta $20.76^{\circ} ; 36.49^{\circ}$ and $42.48^{\circ}$ (JCPDS 44-0706) while copper (I) oxide $\left(\mathrm{Cu}_{2} \mathrm{O}\right)$ was found in 2 theta equal to $40.20^{\circ}$ and $45.72^{\circ}$ (JCPDS 35-1091 and 050667 JCPDS). The $\mathrm{CuO}$ and $\mathrm{Cu}_{2} \mathrm{O}$ nanoparticles average diameter was estimated using Scherrer equation (1), from the diffraction peaks $20.76^{\circ}$ and $45.72^{\circ}$, respectively, which are more intense. The results are shown in Table 2.

The Table 2 shows the estimated size of the cupric oxide nanoparticles $(\mathrm{CuO})$ is between 40 and $78 \mathrm{~nm}$, while the 
Table 2. Copper oxide nanoparticles diameter synthesized by the green method.

\begin{tabular}{ccc}
\hline & \multicolumn{2}{c}{ Nanoparticles diameter $(\mathbf{n m})$} \\
\hline Carbon sample & $\mathrm{CuO}$ & $\mathrm{Cu}_{2} \mathrm{O}$ \\
$\mathbf{1}$ & 47 & 104 \\
$\mathbf{2}$ & 47 & 158 \\
$\mathbf{3}$ & 40 & 147 \\
$\mathbf{4}$ & 50 & 127 \\
$\mathbf{5}$ & 45 & 165 \\
$\mathbf{6}$ & 78 & 151 \\
$\mathbf{7}$ & 75 & 159 \\
$\mathbf{8}$ & 61 & 143 \\
$\mathbf{9}$ & 76 & 114 \\
\hline
\end{tabular}

cuprous oxide nanoparticles $\left(\mathrm{Cu}_{2} \mathrm{O}\right)$ is between $104-165 \mathrm{~nm}$. These values match the literature reports for the diameter of copper oxide nanoparticles synthesized from green methods. It was found $\mathrm{CuO}$ nanoparticles sizes of 5 to $10 \mathrm{~nm} ; 20$ to $30 \mathrm{~nm} ; 48 \mathrm{~nm} ; 140 \mathrm{~nm}$ and $544 \mathrm{~nm}$ obtained by green method using leaves extract of Gloriosa superba, Calotropis gigantea, Tabernaemontana divaricate, Carica papaya and Ficus religiosa, respectively, as reducing agents ${ }^{6,54-57}$. Whereas $\mathrm{Cu}_{2} \mathrm{O}$ nanoparticles sizes were 30 to $50 \mathrm{~nm} ; 60-80 \mathrm{~nm}$ and 100-200 nm, using as reducing agents of nanoparticles leaves extract of Arachis hypogaea L., Tridax procumbens and lignin, respectively ${ }^{5,58,59}$.

The literature presents the use of pomegranate extract in the synthesis of silver nanoparticles with diameters of 20 to 50 $\mathrm{nm}$, gold nanoparticles up to $400 \mathrm{~nm}$ and iron nanoparticles of 10-30 $\mathrm{nm}^{60-63}$. Regarding copper nanoparticles using this reducing agent, studies are still limited, so it is important to evaluate the performance of pomegranate extract also in obtaining these nanoparticles, since its reducing potential is already known.

It is noticeable that there was not a linear relationship between the nanoparticles diameter and the copper concentration used in carbon impregnation. However, each copper oxide nanoparticles had diameters close to each other between samples. Among oxides, the nanoparticles have differences in diameter due to the $\mathrm{CuO}$ monoclinic crystal structure and $\mathrm{Cu}_{2} \mathrm{O}$ cubic crystal structure. With these results, it could be noticed that the phenolic compounds present in plant extract acted as reducing and protective agents, because it was possible to obtain copper oxide in nanometric form without excessive nanoparticles growth ${ }^{64,65}$.

The materials were also texturally characterized by BET specific surface area analysis $\left(\mathrm{S}_{\mathrm{BET}}\right)$, micropore area $\left(\mathrm{S}_{\text {micro }}\right)$, micropore volume $\left(\mathrm{V}_{\text {micro }}\right)$ and pore diameter $\left(\mathrm{D}_{\mathrm{p}}\right)$. Results obtained using NOVAWin program, provided by Quantachrome Instruments, are shown in Table 3.

It can be seen that pure activated carbon has a high specific surface area $\left(\mathrm{S}_{\mathrm{BET}}\right)$ and as expected, this area has decreased
Table 3. Textural characterization parameters of the pure and impregnated coals.

\begin{tabular}{ccccc}
\hline Carbon & $\begin{array}{c}\text { SBET } \\
\left(\mathbf{m}^{\mathbf{2}} / \mathbf{g}\right)\end{array}$ & $\begin{array}{c}\mathbf{S}_{\text {micro }} \\
\left(\mathbf{m}^{2} / \mathbf{g}\right)\end{array}$ & $\begin{array}{c}\mathbf{V}_{\text {micro }} \\
\left(\mathbf{c m}^{3} / \mathbf{g}\right)\end{array}$ & $\mathbf{D}_{\mathbf{p}}(\mathbf{\AA})$ \\
\hline Pure & 696 & 423 & 0.19 & 9.7 \\
$\mathbf{1}$ & 596 & 391 & 0.18 & 10.5 \\
$\mathbf{2}$ & 619 & 371 & 0.16 & 9.9 \\
$\mathbf{3}$ & 604 & 353 & 0.16 & 10.8 \\
$\mathbf{4}$ & 608 & 376 & 0.17 & 10.4 \\
$\mathbf{5}$ & 613 & 323 & 0.14 & 10.2 \\
$\mathbf{6}$ & 640 & 334 & 0.15 & 10.5 \\
$\mathbf{7}$ & 599 & 340 & 0.15 & 10.0 \\
$\mathbf{8}$ & 638 & 348 & 0.15 & 10.5 \\
$\mathbf{9}$ & 628 & 321 & 0.14 & 10.4 \\
\hline
\end{tabular}

with the addition of copper used in carbon modification. Micropore volume and area also decreased compared to pure carbon and this is due to the partial micropores obstruction by copper oxide nanoparticles. However, the difference in size of the pore diameter between the carbons was low, reaching $7.6 \%$ as the highest difference among all diameter values. This shows the nanoparticles impregnation does not significantly block the entry and the channel pore. Park and Jang $^{66}$ obtained similar results with silver impregnation on activated carbon.

SEM and EDS analysis were performed to characterize the morphologic and elemental structure of pure and impregnated carbons surface. Figures 2, 3, 4 and 5 show SEM images and EDS spectra of pure and impregnated carbons with $0.5 \%$, $1 \%$ and $1.5 \% \mathrm{Cu}-36 \mathrm{~h}$, respectively. The remaining samples, obtained with 12 or 24 hours, showed similar morphologies to those obtained with 36 hours of impregnation and therefore they were omitted.

Through pure carbon micrograph obtained by SEM (Figure 2), it was found that its surface structure is porous, with uniformly distributed pores over the carbonaceous matrix, which enables the achievement of a high surface area value as presented earlier in the BET analysis results. After carbons modification (Figures 3, 4 and 5), it was observed that the surface structure remained porous, with different pore sizes distributed over the surface. Besides, there was the emergence of small particles on the carbon matrix, although the difference between the images was not significant, suggesting that most part of the copper oxide nanoparticles are deposited within the pores. This behavior was also observed by Park et al. ${ }^{67}$ when impregnating iron oxide nanoparticles on activated carbon.

The EDS spectrum obtained confirm the presence of copper element in activated carbon samples impregnated with the metal. The same element was not detected in the sample of pure activated carbon, in which peaks of carbon, oxygen, gold (due to sample covering for the SEM analysis) 


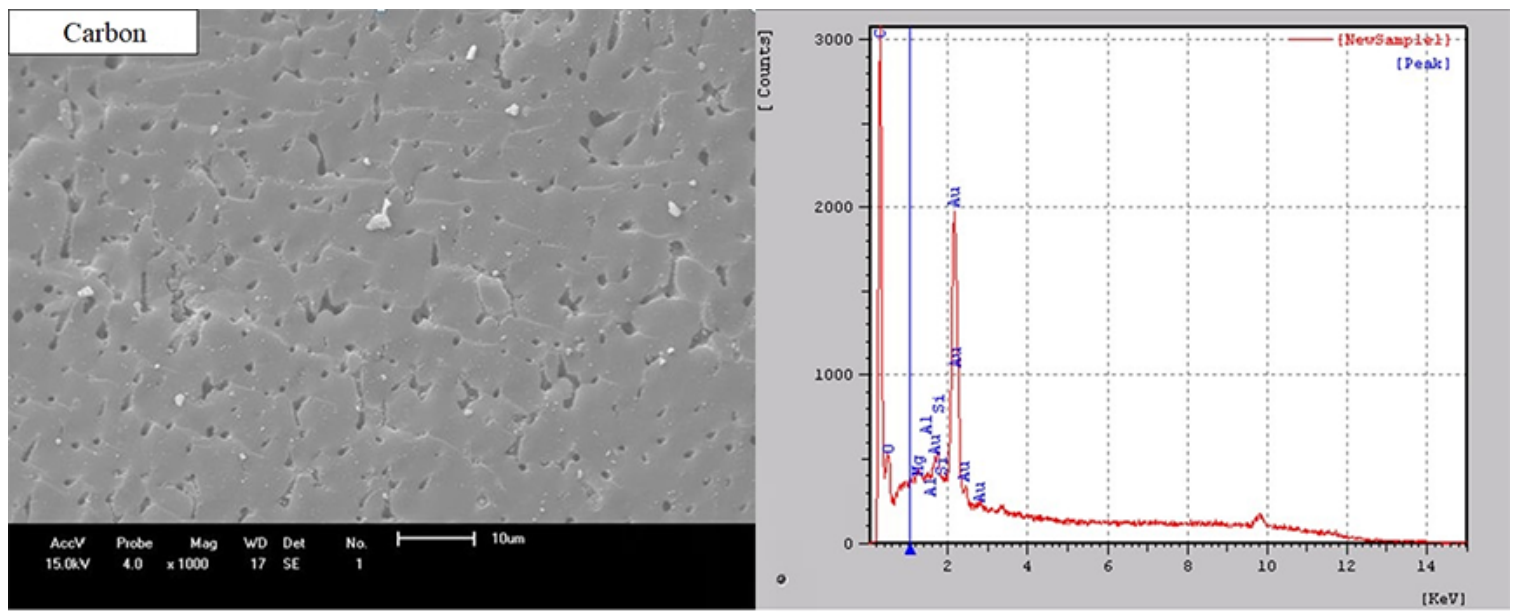

Figure 2. Micrograph obtained by SEM and EDS spectra of pure activated carbon.

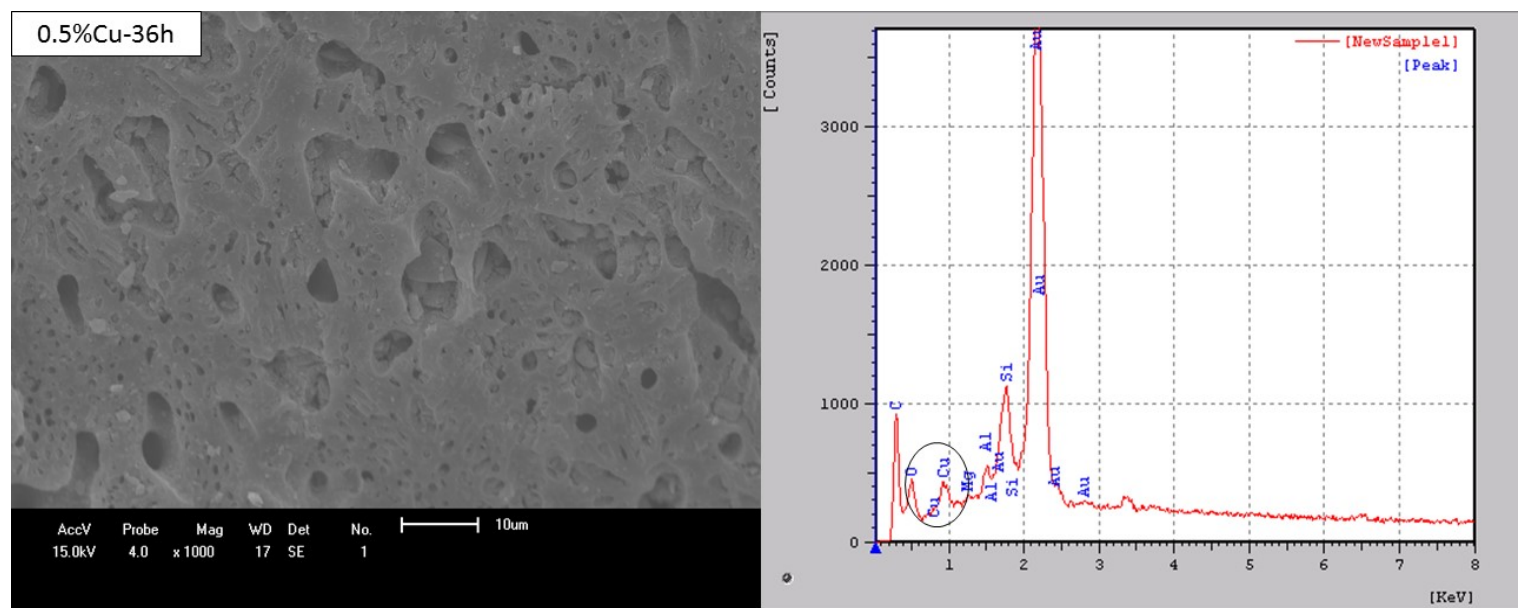

Figure 3. Micrograph obtained by SEM and EDS spectra of carbon impregnated with $0.5 \% \mathrm{Cu}-36 \mathrm{~h}$.

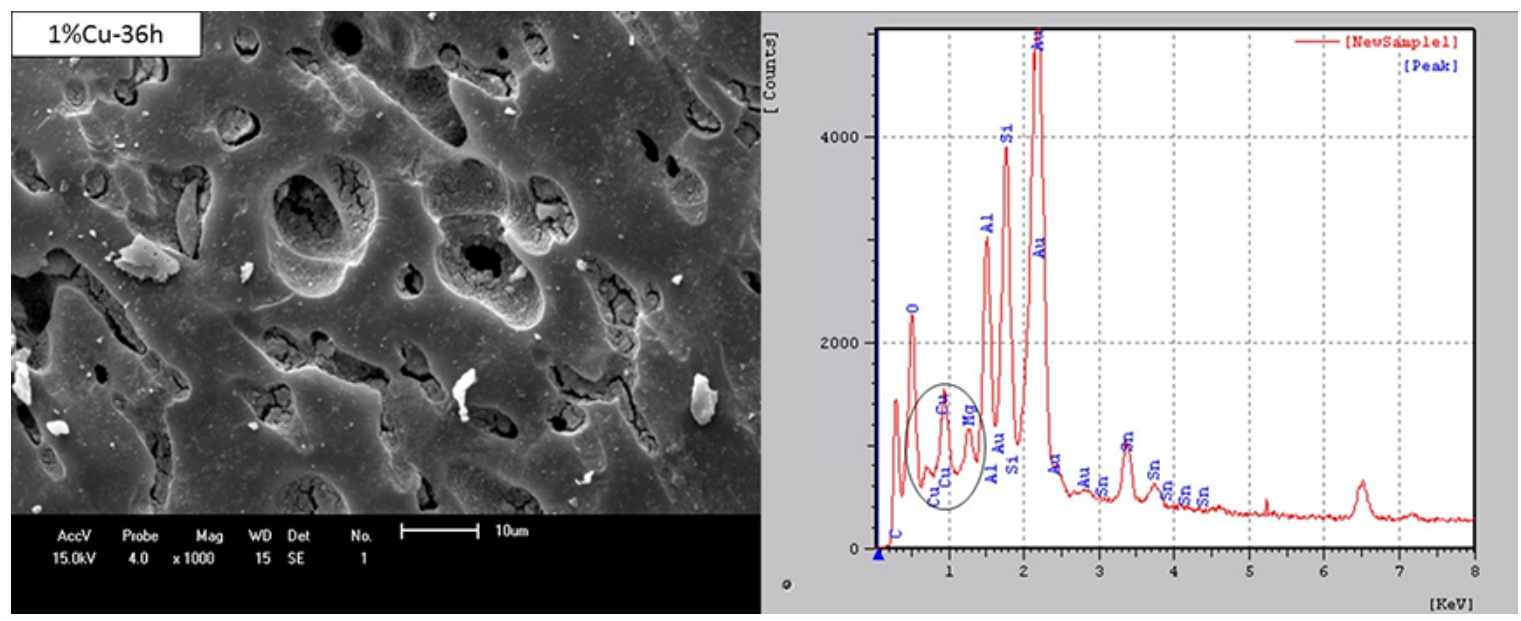

Figure 4. Micrograph obtained by SEM and EDS spectra of carbon impregnated with $1 \% \mathrm{Cu}-36 \mathrm{~h}$ 


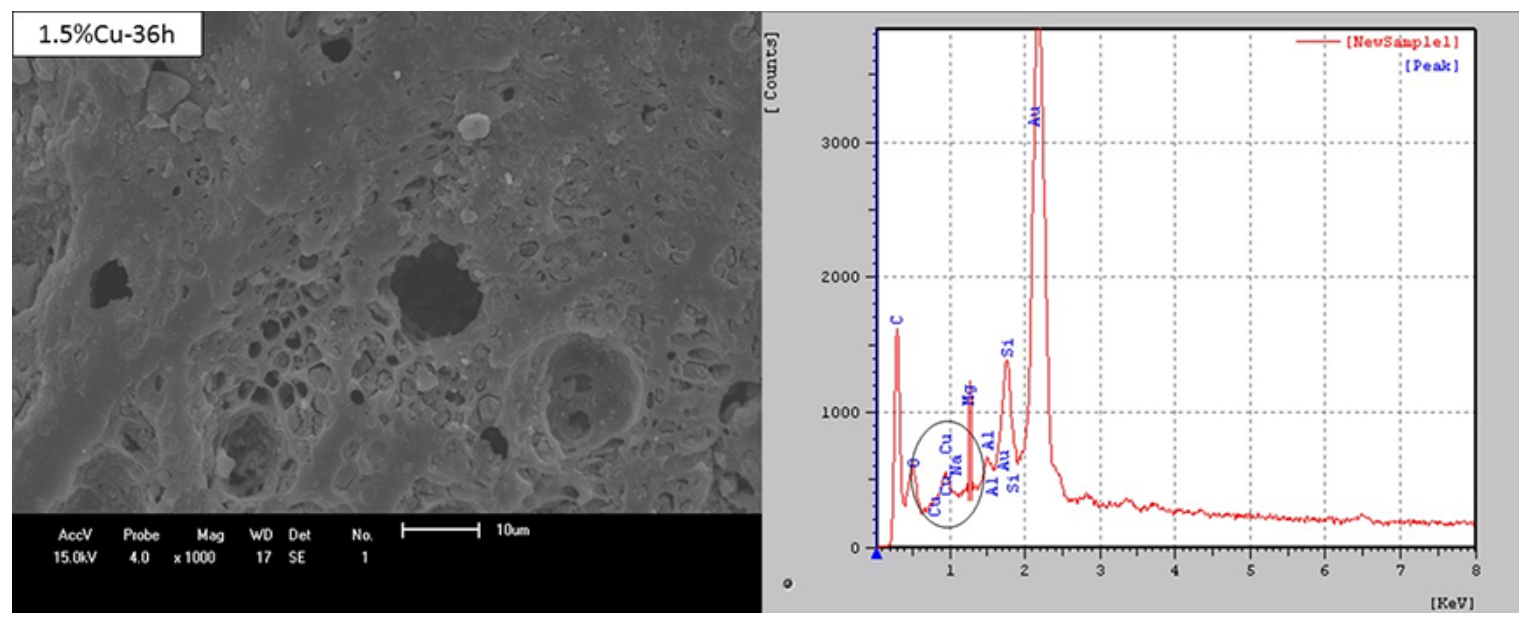

Figure 5. Micrograph obtained by SEM and EDS spectra of carbon impregnated with $1.5 \% \mathrm{Cu}-36 \mathrm{~h}$

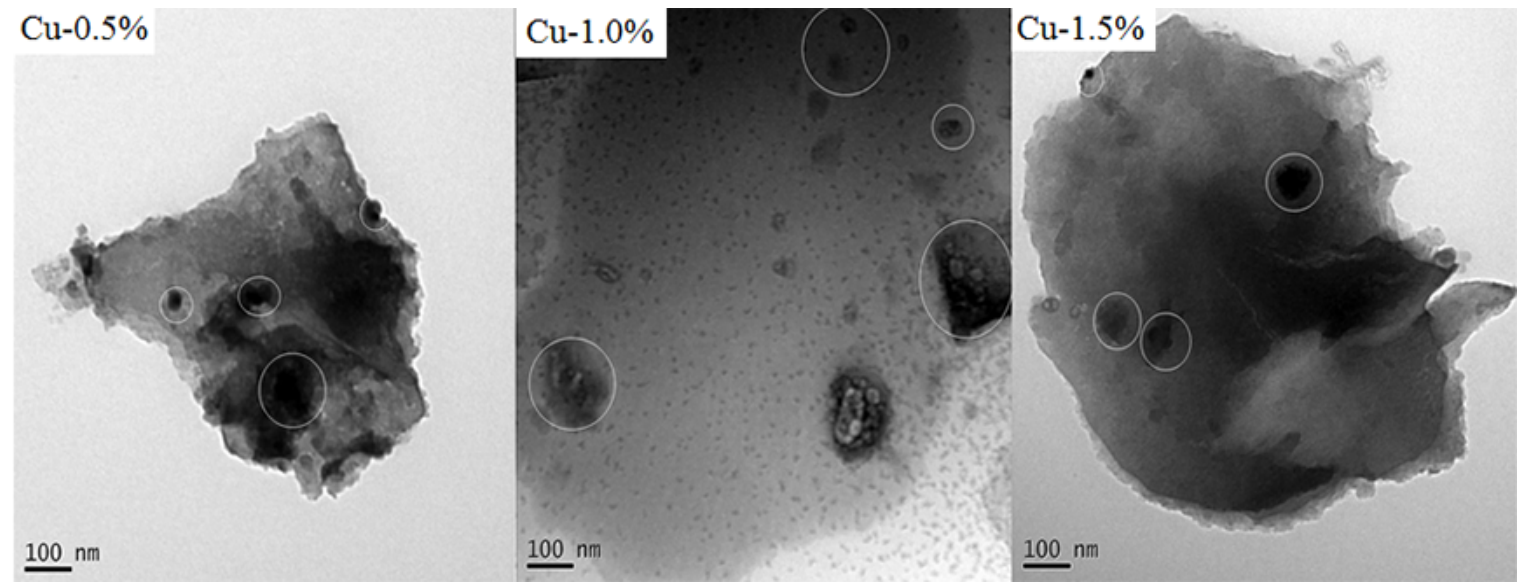

Figure 6. TEM images of impregnated carbons impregnated with $0.5 \% \mathrm{Cu}, 1.0 \% \mathrm{Cu}$ and $1.5 \% \mathrm{Cu}$, in $36 \mathrm{~h}$

were found in addition to the metals $\mathrm{Al}, \mathrm{Si}$ and $\mathrm{Mg}$, typical of biomass, since activated carbon was produced from palm coconut.

Still on the nanoparticles morphology evaluation, TEM carbons images impregnated with copper oxide nanoparticles were obtained, as shown in Figure 6 for the same samples showed in SEM and EDS figures. The remaining samples impregnated with $\mathrm{Cu}$ showed similar behavior, and thus their photomicrographs are not displayed.

Figure 6 shows the carbonaceous matrix grayish with darker particles, typical of metal particles, in this case, copper compounds nanoparticles. In TEM images, the presence of $\mathrm{Cu}$ is observed, in the form of nanoparticles or clusters. It is noted that the copper oxide nanoparticles have predominantly spherical shapes, and the most extensive dark bands are agglomerates of such particles. As confirmed by the XRD analysis (Figure 1), the largest nanoparticles exceed little more than $100 \mathrm{~nm}$. Kumar et al. ${ }^{68}$ also identified through TEM images copper oxide nanoparticles in spherical shape with a diameter of approximately $53 \mathrm{~nm}$, synthesized by green method using Andean blackberry fruit and leaf extract.
Table 4 presents the results of the impregnation efficiency ( $\eta$ ) for each impregnated carbon.

Table 4 shows that, as expected, pure activated carbon did not present copper in its composition. It is also possible to verify that the impregnation efficiency was higher using impregnation solutions with lower percentages of copper, reaching $100 \%$ efficiency in the coal containing $0.5 \% \mathrm{Cu}$ $12 \mathrm{~h}$. Impregnation efficiencies of 65 and $52 \%$ were obtained for $1 \%$ and $1.5 \% \mathrm{Cu}$, respectively. The same behavior was observed for all impregnation times evaluated. The results demonstrate that increasing the amount of loaded copper does not lead to increased impregnation efficiency. This effect is probably related to the limited number of sites available for the impregnation of metal particles.

These nanoparticle characterization results indicate that the pomegranate extract acted as an excellent copper agent reducing. The use of pomegranate extracts was studied by Machado et al. ${ }^{62}$ to production of zero-valent iron nanoparticles. The authors studied the antioxidant capacity (as measured by the FRAP method) of several leaf extracts, and have found 
Table 4. Efficiency of impregnation of the green method analyzed by means of TXRF

\begin{tabular}{cc}
\hline Carbon & $\boldsymbol{\eta}(\%)$ \\
\hline Pure & $*$ \\
$0.5 \% \mathrm{Cu}-12 \mathrm{~h}$ & 100 \\
$1 \% \mathrm{Cu}-12 \mathrm{~h}$ & 65 \\
$1.5 \% \mathrm{Cu}-12 \mathrm{~h}$ & 52 \\
$0.5 \% \mathrm{Cu}-24 \mathrm{~h}$ & 86 \\
$1 \% \mathrm{Cu}-24 \mathrm{~h}$ & 75 \\
$1.5 \% \mathrm{Cu}-24 \mathrm{~h}$ & 67 \\
$0.5 \% \mathrm{Cu}-36 \mathrm{~h}$ & 84 \\
$1 \% \mathrm{Cu}-36 \mathrm{~h}$ & 84 \\
$1.5 \% \mathrm{Cu}-36 \mathrm{~h}$ & 57 \\
\hline
\end{tabular}

*The pure activated carbon did not present copper in its composition.

that the oak and pomegranate tree leaf extracts provided the highest antioxidant capacity $\left(>40 \mathrm{mmol} \mathrm{L}^{-1}\right)$, indicating that those leaves were the most appropriate for nanoparticles production. Probably, this high antioxidant capacity should be due to the high concentration of tannins and flavonoids present in pomegranate leaves ${ }^{69}$.

The point of zero charge of the obtained carbons was evaluated in order to understand how the load distribution on surface of the samples occurs when varying the $\mathrm{pH}$ solution. Table 5 shows the $\mathrm{pH}_{\mathrm{PZCZ}}$ values of the samples.

Table 5 shows the $\mathrm{pH}_{\mathrm{PzC}}$ is about 6 to 7 for the carbons analyzed. In this zone, the carbon surfaces have a neutral charge. In solutions with $\mathrm{pH}$ below PZC, the carbons have a positive surface charge and in $\mathrm{pH}$ above the $\mathrm{PZC}$, the surface charge is negative. There was no significant $\mathrm{pH}_{\mathrm{PZC}}$ variation with copper oxide nanoparticles impregnation on the activated carbon, so it can be concluded that the carbons surfaces present neutral properties. Tseng and $\mathrm{Wey}^{70}$ impregnated $\mathrm{CuO}$ on activated carbon of coconut shell and they also identified a neutral surface charge in pure activated carbon $\left(\mathrm{pH}_{\mathrm{PZC}}=6.3\right)$, however, since the impregnation methodology used acid treatment, $\mathrm{pH}_{\mathrm{PZC}}$ of impregnated carbons was around 3.8 , due to the increase of acid groups on material surface. In this study, no chemical reagent (acid or basic) was used in impregnation of the nanoparticles; therefore, there was no change in the neutral character of the support surface. Besides, copper is in the form of copper oxide, which does not change the surface charge.

Table 5. $\mathrm{pH}_{\mathrm{PCZ}}$ of pure activated carbon and copper oxide impregnated carbon.

\begin{tabular}{cccc}
\hline Carbon & $\mathbf{p H}_{\mathbf{P Z C}}$ & Carbon & $\mathbf{p H}_{\mathbf{P Z C}}$ \\
\hline Pure & 6.86 & $\mathbf{5}$ & 6.39 \\
$\mathbf{1}$ & 6.40 & $\mathbf{6}$ & 6.14 \\
$\mathbf{2}$ & 6.10 & $\mathbf{7}$ & 7.23 \\
$\mathbf{3}$ & 6.04 & $\mathbf{8}$ & 6.38 \\
$\mathbf{4}$ & 7.03 & $\mathbf{9}$ & 6.13 \\
\hline
\end{tabular}

\subsection{Adsorption experiments}

The pollutant removal assays showed the efficiency of activated carbon impregnated with copper oxide nanoparticles in the adsorption. Since all prepared carbons showed nanoparticles on its surface, fact confirmed by XRD analysis, impregnated carbons with three copper concentrations in the intermediate time of $24 \mathrm{~h}$ were chosen for comparison. Table 6 presents the results of these tests.

Table 6 shows that nitrate adsorption capacity is directly proportional to the amount of copper present in the activated carbon, where the impregnation with $1.5 \% \mathrm{Cu}$ increased more than 4 times the nitrate removal capacity by pure activated carbon. This is due to the fact that nitrate is an anion, therefore it binds by electrostatic forces to the copper oxide nanoparticles present on carbon surface, leading to higher nitrate ions values removal from solution.

As concern to the contaminants atrazine and caffeine, it is observed that the maximum adsorption capacities practically did not suffer interference by the presence of nanoparticles, keeping their values very close to those obtained with pure carbon. For diclofenac contaminant, a worse result was observed with $0.5 \% \mathrm{Cu}$ carbon. For this contaminant, $1.5 \% \mathrm{Cu}$ was required to increase the same adsorption capacity of the pure carbon.

The removal of atrazine ${ }^{19,71}$, caffeine and diclofenac ${ }^{33}$ by adsorption has been studied. Adsorption capacity values higher than those found in the present study are observed. However, one should consider the severe temperature and reagent methods used by the authors.

It can be seen that impregnated carbon with $\mathrm{Cu} 1.5 \%$ achieved a performance as good as the commercial pure carbon for removal of contaminants atrazine, caffeine and diclofenac, removing almost $100 \%$ for atrazine and caffeine. In these cases, since three organic contaminants were used, there is no charges generation in these molecules in neutral $\mathrm{pH}$, thus adsorption possibly occurs in carbon and there is no influence of copper oxide nanoparticles, different from the nitrate, which due to the punctual charges generated over the coal may have electrostatic interactions with copper. Besides, it is important to notice that pore blocking caused by copper oxide nanoparticles did not influence the organic compounds removal, since the impregnated carbon removed efficiently all pollutants.

Considering the behavior presented by impregnated carbons in the intermediate time for the different pollutants, adsorption tests only for nitrate were performed with the remaining impregnated carbons, because results were more satisfactory for this contaminant, and the tests were performed in order to verify metal concentration and contact time of impregnation influences in the adsorption process efficiency, as shown in Figure 7. 
Table 6. Adsorption capacity of the multiple pollutants presented by the pure coal and impregnated with $\mathrm{Cu}$ and residual concentration at the solution.

\begin{tabular}{|c|c|c|c|c|c|c|c|c|}
\hline & \multicolumn{2}{|c|}{ Atrazine $^{\mathrm{a}}$} & \multicolumn{2}{|c|}{ Caffeine $^{b}$} & \multicolumn{2}{|c|}{ Diclofenac $^{\text {b }}$} & \multicolumn{2}{|c|}{ Nitrate $^{b}$} \\
\hline Adsorbent & $\mathrm{q}_{\mathrm{e}}\left(\mathrm{mg} \mathrm{g}^{-1}\right)$ & $\mathrm{C}_{\text {final }}\left(\mathrm{mg} \mathrm{L}^{-1}\right)$ & $\mathrm{q}_{\mathrm{e}}\left(\mathrm{mg} \mathrm{g}^{-1}\right)$ & $\mathrm{C}_{\text {final }}\left(\mathrm{mg} \mathrm{L}^{-1}\right)$ & $\mathrm{q}_{\mathrm{e}}\left(\mathrm{mg} \mathrm{g}^{-1}\right)$ & $\mathrm{C}_{\text {final }}\left(\mathrm{mg} \mathrm{L}^{-1}\right)$ & $\mathrm{q}_{\mathrm{e}}\left(\mathrm{mg} \mathrm{g}^{-1}\right)$ & $\mathrm{C}_{\text {final }}\left(\mathrm{mg} \mathrm{L}^{-1}\right)$ \\
\hline $\begin{array}{l}\text { Pure } \\
\text { carbon }\end{array}$ & $\begin{array}{l}1.27 \pm \\
0.000\end{array}$ & $\begin{array}{c}0.009 \pm \\
0.001\end{array}$ & $\begin{array}{c}41.6 \pm \\
0.131\end{array}$ & $2.1 \pm 0.315$ & $\begin{array}{c}16.9 \pm \\
0.408\end{array}$ & $\begin{array}{c}61.4 \pm \\
0.980\end{array}$ & $0.93 \pm 0.015$ & $\begin{array}{c}89.4 \pm \\
0.150\end{array}$ \\
\hline $\begin{array}{c}0.5 \% \mathrm{Cu}- \\
24 \mathrm{~h}\end{array}$ & $\begin{array}{l}1.26 \pm \\
0.005\end{array}$ & $\begin{array}{c}0.056 \pm \\
0.020\end{array}$ & $\begin{array}{c}40.8 \pm \\
0.085\end{array}$ & $4.0 \pm 0.205$ & $11.5 \pm 0.392$ & $\begin{array}{c}74.5 \pm \\
0.940\end{array}$ & $2.48 \pm 0.062$ & $\begin{array}{c}73.8 \pm \\
0.625\end{array}$ \\
\hline $1 \% \mathrm{Cu}-24 \mathrm{~h}$ & $\begin{array}{l}1.25 \pm \\
0.005\end{array}$ & $\begin{array}{c}0.069 \pm \\
0.019\end{array}$ & $\begin{array}{c}38.5 \pm \\
0.371\end{array}$ & $9.5 \pm 0.890$ & $\begin{array}{c}14.8 \pm \\
0.265\end{array}$ & $\begin{array}{c}66.5 \pm \\
0.635\end{array}$ & $3.52 \pm 0.007$ & $\begin{array}{c}63.4 \pm \\
0.075\end{array}$ \\
\hline $\begin{array}{c}1.5 \% \mathrm{Cu}- \\
24 \mathrm{~h}\end{array}$ & $\begin{array}{c}1.27 \pm \\
0.000\end{array}$ & $\begin{array}{c}0.015 \pm \\
0.002\end{array}$ & $\begin{array}{c}41.0 \pm \\
0.038\end{array}$ & $3.7 \pm 0.090$ & $\begin{array}{c}16.9 \pm \\
0.285\end{array}$ & $\begin{array}{c}61.5 \pm \\
0.685\end{array}$ & $4.09 \pm 0.057$ & $\begin{array}{c}57.8 \pm \\
0.575\end{array}$ \\
\hline
\end{tabular}

${ }^{a}$ Cinitial: $5 \mathrm{mg} \mathrm{L}^{-1}$;

${ }^{\mathrm{b}}$ Cinitial: $100 \mathrm{mg} \mathrm{L}^{-1}$

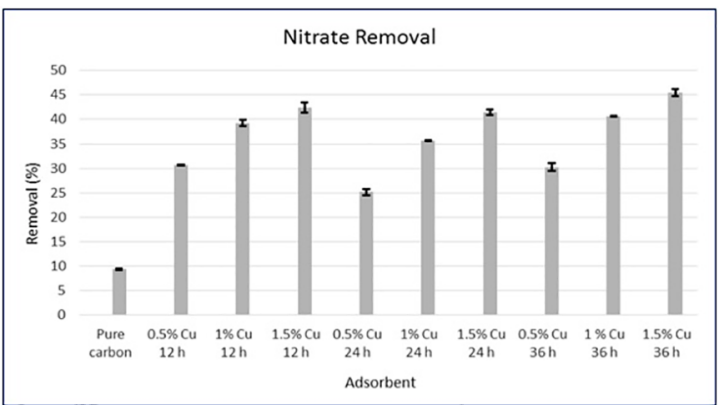

Figure 7. Nitrate removal of pure and impregnated with copper oxide carbons

It is observed in Figure 7 that the amount of nitrate removed from the water increases proportionally as the amount of copper present in the carbon is increased, where carbons impregnated with $1.5 \%$ of $\mathrm{Cu}$ removed more than $40 \%$ nitrate, whereas pure carbon removed less than $10 \%$. The standard deviation of each sample was calculated according to equation (3) and it is represented in black by the error bars on the graph. There were no major variations between the measurements of the samples, being error range between $0.08 \%$ and $1.01 \%$. Nitrate removal efficiency has not presented linear relation with impregnation time, since the time of $12 \mathrm{~h}$ showed greater removal than time of 24 h, especially for carbon impregnated with $0.5 \%$ and $1 \%$ of $\mathrm{Cu}$. Therefore, the smallest contact time is sufficient for the proposed objective.

Considering the results in Table 6 and Figure 7, it can be said that activated carbon impregnation with copper oxide nanoparticles expands the application area of the commercial activated carbon, since in addition to the contaminants naturally removed by carbon; the impregnation significantly increased the nitrate removal potential from water. As long as it is common to find multiple contaminants in natural waters, this is a promising alternative to conventional methods of treatment.

\section{Conclusion}

Obtainment and impregnation green method of copper oxide nanoparticles on the surface of activated carbon using pomegranate leaf extract, as a reducing/stabilizer agent, was effective for achieving the objectives. It has been found $\mathrm{Cu}_{2} \mathrm{O}$ nanoparticles with diameters between 104 and $165 \mathrm{~nm}$ and $\mathrm{CuO}$ measuring between 40 and $78 \mathrm{~nm}$ on the activated carbons surfaces. The impregnated carbons showed a great water pollutants removal, in particular nitrate, providing a non-polluting and cost-effective alternative to the conventional treatment methods. Among the samples, carbon impregnated with $1.5 \% \mathrm{Cu}-24 \mathrm{~h}$ can be highlighted, because it showed a removal similar to pure carbon for organic contaminants, however it increased carbon efficiency in nitrate ions removal in more than four times. So, an impregnation time of $24 \mathrm{~h}$ is sufficient to obtain copper oxide nanoparticles on carbon activated with a good pollutant removal potential.

\section{Acknowledgments}

This work is financially supported by Brazilian National Council for Scientific and Technological Development (CNPq).

\section{References}

1. Khot LR, Sankaran S, Maja JM, Ehsani R, Schuster EW. Applications of nanomaterials in agricultural production and crop protection: A review. Crop Protection. 2012;35:64-70.

2. Chang YN, Zhang M, Xia L, Zhang J, Xing G. The Toxic Effects and Mechanisms of $\mathrm{CuO}$ and $\mathrm{ZnO}$ Nanoparticles. Materials. 2012;5(12):2850-2871.

3. Tan S, Zou W, Jiang F, Tan S, Liu Y, Yuan D. Facile fabrication of copper-supported ordered mesoporous carbon for antibacterial behavior. Materials Letters. 2010;64(20):2163-2166. 
4. Wang T, Lin J, Chen Z, Megharaj M, Naidu R. Green synthesized iron nanoparticles by green tea and eucalyptus leaves extracts used for removal of nitrate in aqueous solution. Journal of Cleaner Production. 2014;83:413-419.

5. Ramesh C, HariPrasad M, Ragunathan V. Effect of Arachis hypogaea L. Leaf Extract on Barfoed's Solution; Green Synthesis of Cu2O Nanoparticles and its Antibacterial Effect. Current Nanoscience. 2011;7(6):995-999.

6. Sharma JK, Akhtar MS, Ameen S, Srivastava P, Singh G. Green synthesis of $\mathrm{CuO}$ nanoparticles with leaf extract of Calotropis gigantea and its dye-sensitized solar cells applications. Journal of Alloys and Compounds. 2015;632:321-325.

7. Edison TJI, Sethuraman MG. Biogenic robust synthesis of silver nanoparticles using Punica granatum peel and its application as a green catalyst for the reduction of an anthropogenic pollutant 4-nitrophenol. Spectrochimica Acta Part A: Molecular and Biomolecular Spectroscopy. 2013;104:262-264.

8. Venkateswarlu S, Kumar BN, Prathima B, SubbaRao Y, Jyothi NVV. A novel green synthesis of Fe3O4 magnetic nanorods using Punica Granatum rind extract and its application for removal of $\mathrm{Pb}(\mathrm{II})$ from aqueous environment. Arabian Journal of Chemistry. 2014. In Press.

9. Ganeshkumar M, Sathishkumar M, Ponrasu T, Dinesh MG, Suguna L. Spontaneous ultra fast synthesis of gold nanoparticles using Punica granatum for cancer targeted drug delivery. Colloids and Surfaces B: Biointerfaces. 2013;106:208-216.

10. da Silva JAT, Rana TS, Narzary D, Verma N, Meshram DT, Ranade SA. Pomegranate biology and biotechnology: A review. Scientia Horticulturae. 2013;160:85-107.

11. Bragança LFFPG, Avillez RR, Moreira CR, Pais da Silva MI. Synthesis and characterization of Co-Fe nanoparticles supported on mesoporous silicas. Materials Chemistry and Physics. 2013;138(1):17-28.

12. Wouters B, Sheng X, Boschin A, Breugelmans T, Ahlberg E, Vankelecom IF, et al. The electrocatalytic behaviour of $\mathrm{Pt}$ and $\mathrm{Cu}$ nanoparticles supported on carbon nanotubes for the nitrobenzene reduction in ethanol. Electrochimica Acta. 2013;111:405-410.

13. Liu X, Wang A, Li L, Zhang T, Mou CY, Lee JF. Synthesis of $\mathrm{Au}-\mathrm{Ag}$ alloy nanoparticles supported on silica gel via galvanic replacement reaction. Progress in Natural Science: Materials International. 2013;23(3):317-325.

14. Li L, Chen M, Huang G, Yang N, Zhang L, Wang H, et al. A green method to prepare $\mathrm{Pd}-\mathrm{Ag}$ nanoparticles supported on reduced graphene oxide and their electrochemical catalysis of methanol and ethanol oxidation. Journal of Power Sources. 2014;263:13-21.

15. Yamaguchi NU, Bergamasco R, Hamoudi S. Magnetic MnFe2O4graphene hybrid composite for efficient removal of glyphosate from water. Chemical Engineering Journal. 2016;295:391-402.

16. Kalijadis AM, Vukcevic MM, Jovanovic ZM, Lauševic ZV, Lauševic MD. Characterization of surface oxygen groups on different carbon materials by the Boehm method and temperature programmed desorption. Journal of The Serbian Chemical Society. 2011;76(5):757-768.
17. Hosseini S, Bayesti I, Marahel E, Babadi FE, Abdullah LC, Choong TS. Adsorption of carbon dioxide using activated carbon impregnated with $\mathrm{Cu}$ promoted by zinc. Journal of the Taiwan Institute of Chemical Engineers. 2015;52:109-117.

18. Tepuš B, Simonic M, Petrinic I. Comparison between nitrate and pesticide removal from ground water using adsorbents and NF and RO membranes. Journal of Hazardous Materials. 2009;170(2-3):1210-1217.

19. Gupta VK, Gupta B, Rastogi A, Agarwal S, Nayak A. Pesticides removal from waste water by activated carbon prepared from waste rubber tire. Water Research. 2011;45(13):4047-4055.

20. Ota K, Amano Y, Aikawa M, Machida M. Removal of nitrate ions from water by activated carbons (ACs)-Influence of surface chemistry of ACs and coexisting chloride and sulfate ions. Applied Surface Science. 2013;276:838-842.

21. Sotelo JL, Rodríguez AR, Mateos MM, Hernández SD, Torrellas SA, Rodríguez JG. Adsorption of pharmaceutical compounds and an endocrine disruptor from aqueous solutions by carbon materials. Journal of Environmental Science and Health, Part B. 2012;47(7):640-652.

22. Álvarez S, Ribeiro RS, Gomes HT, Sotelo JL, García J. Synthesis of carbon xerogels and their application in adsorption studies of caffeine and diclofenac as emerging contaminants. Chemical Engineering Research and Design. 2015;95:229-238.

23. Caldas SS, Bolzan CM, Guilherme JR, Silveira MA, Escarrone AL, Primel EG. Determination of pharmaceuticals, personal care products, and pesticides in surface and treated waters: method development and survey. Environmental Science and Pollution Research International. 2013;20(8):5855-5863.

24. Lin $\mathrm{SH}, \mathrm{Wu} \mathrm{CL}$. Removal of nitrogenous compounds from aqueous solution by ozonation and ion exchange. Water Research. 1996;30(8):1851-1857.

25. Nguyen LN, Hai FI, Yang S, Kang J, Leusch FDL, Roddick F, et al. Removal of pharmaceuticals, steroid hormones, phytoestrogens, UV-filters, industrial chemicals and pesticides by Trametes versicolor: Role of biosorption and biodegradation. International Biodeterioration \& Biodegradation. 2014;88:169175.

26. Hayes T, Haston K, Tsui M, Hoang A, Haeffele C, Vonk A. Atrazine-induced hermaphroditism at $0.1 \mathrm{ppb}$ in American leopard frogs (Rana pipiens): laboratory and field evidence. Environmental Health Perspectives. 2003;111(4):568-575.

27. Hayes TB, Khoury V, Narayan A, Nazir M, Park A, Brown T, et al Atrazine induces complete feminization and chemical castration in male African clawed frogs (Xenopus laevis). Proceedings of the National Academy of Sciences. 2010;107(10):4612-4617.

28. Tillitt DE, Papoulias DM, Whyte JJ, Richter CA. Atrazine reduces reproduction in fathead minnow (Pimephales promelas). Aquatic Toxicology. 2010;99(2):149-159.

29. Salaberria I, Hansen BH, Asensio V, Olsvik PA, Andersen RA, Jenssen BM. Effects of atrazine on hepatic metabolism and endocrine homeostasis in rainbow trout (Oncorhynchus mykiss). Toxicology and Applied Pharmacology. 2009;234(1):98-106. 
30. MacLennan PA, Delzell E, Sathiakumar N, Myers SL, Cheng H, Grizzle W, et al. Cancer incidence among triazine herbicide manufacturing workers. Journal of Occupational and Environmental Medicine. 2002;44(11):1048-1058.

31. Fan W, Yanase T, Morinaga H, Gondo S, Okabe T, Nomura $\mathrm{M}$, et al. Atrazine-lnduced aromatase expression is SF-1 dependent: Implications for endocrine disruption in wildlife and reproductive cancers in humans. Environmental Health Perspectives. 2007;115(5):720-727.

32. Buerge II, Poiger T, Müller MD, Buser HR. Caffeine, an anthropogenic marker for wastewater contamination of surface waters. Environmental Science \& Technology. 2003;37(2003):691700 .

33. Torrellas SA, Lovera RG, Escalona N, Sepúlveda C, Sotelo JL, García J. Chemical-activated carbons from peach stones for the adsorption of emerging contaminants in aqueous solutions. Chemical Engineering Journal. 2015;279:788-798.

34. Wang A, Li L, Zang F, Fang Y. Amperometric detection of three purine alkaloids following their separation by micellar electrokinetic capillary chromatography. Analytica Chimica Acta. 2000;419(2):235-242.

35. Tiwari D, Lalhriatpuia C, Lee SM. Hybrid materials in the removal of diclofenac sodium from aqueous solutions: Batch and column studies. Journal of Industrial and Engineering Chemistry. 2015;30:167-173.

36. Öztürk N, Bektas TE. Nitrate removal from aqueous solution by adsorption onto various materials. Journal of Hazardous Materials. 2004;112(2004):155-162.

37. Feleke Z, Sakakibara Y. A bio-electrochemical reactor coupled with adsorber for the removal of nitrate and inhibitory pesticide. Water Research. 2000;36(12):3092-3102.

38. Sotelo JL, Ovejero G, Rodríguez A, Álvarez S, Galán J, García J. Competitive adsorption studies of caffeine and diclofenac aqueous solutions by activated carbon. Chemical Engineering Journal. 2014;240:443-453.

39. Lladó J, Lao-Luque C, Ruiz B, Fuente E, Solé-Sardans M, Dorado AD. Role of activated carbon properties in atrazine and paracetamol adsorption equilibrium and kinetics. Process Safety and Environmental Protection. 2015;95:51-59.

40. Liu G, Yang X, Li T, She Y, Wang S, Wang J, et al. Preparation of a magnetic molecularly imprinted polymer using g-C3N4-Fe3O4 for atrazine adsorption. Materials Letters. 2015;160:472-475.

41. Rajeswari A, Amalraj A, Pius A. Adsorption studies for the removal of nitrate using chitosan/PEG and chitosan/PVA polymer composites. Journal of Water Process Engineering. 2016;9:123-134.

42. Squillace PJ, Scott JC, Moran MJ, Nolan B, Kolpin DW. VOCs, pesticides, nitrate, and their mixtures in groundwater used for drinking water in the United States. Environmental Science \& Technology. 2002;36(9):1923-1930.

43. Net S, Rabodonirina S, Sghaier RB, Dumoulin D, Chbib C, Tlili I, et al. Distribution of phthalates, pesticides and drug residues in the dissolved, particulate and sedimentary phases from transboundary rivers (France-Belgium). Science of the Total Environment. 2015;521-522:152-159.
44. Troiano J, Garretson C, Dasilva A, Marade J, Barry T. Pesticide and Nitrate Trends in Domestic Wells Where Pesticide Use Is Regulated in Fresno and Tulare Counties, California. Journal of Environmental Quality. 2013;42(2013):1711-1723.

45. Horváth G, Kawazoe K. Method for the calculation of effective pore size distribution in molecular sieve carbon. Journal of Chemical Engineering of Japan. 1983;16(6):470-475.

46. Brunauer S, Emmett PH, Teller E. Adsorption of Gases in Multimolecular Layers. Journal of the American Chemical Society. 1938;60(2):309-319.

47. Lippens BC, de Boer JH. Studies on pore systems in catalysts: V. The t method. Journal of Catalysis. 1965;4(3):319-323.

48. Guilarduci VVS, Mesquita JP, Martelli PB, Gorgulho HF. Adsorção de fenol sobre carvão ativado em meio alcalino. Química Nova. 2006;29(6):1226-1232.

49. Mimura AMS, Vieira TVA, Martelli PB, Gorgulho HF. Aplicação da casca de arroz na adsorção dos íons $\mathrm{Cu} 2+, \mathrm{A} 13+, \mathrm{Ni} 2+$ e Zn2+. Química Nova. 2010;33(6):1279-1284.

50. Lima SB, Borges SMS, Rangel MC, Marchetti SG. Effect of iron content on the catalytic properties of activated carbonsupported magnetite derived from biomass. Journal of the Brazilian Chemical Society. 2013;24(2):344-354.

51. Nasrollahzadeh M, Jaleh B, Fakhri P, Zahraei A, Ghadery E. Synthesis and catalytic activity of carbon supported copper nanoparticles for the synthesis of aryl nitriles and 1, 2, 3-triazoles. RSC Advances. 2015;5(4):2785-2793.

52. Cui J, Yang Y, Hu Y, Li F. Rice husk based porous carbon loaded with silver nanoparticles by a simple and cost-effective approach and their antibacterial activity. Journal of Colloid and Interface Science. 2015;455:117-124.

53. Foletto EL, Gratieri E, Oliveira LH, Jahn SL. Conversion of rice hull ash into soluble sodium silicate. Materials Research. 2006;9(3):335-338.

54. Naika HR, Lingaraju K, Manjunath K, Kumar D, Nagaraju G, Suresh $\mathrm{D}$, et al. Green synthesis of $\mathrm{CuO}$ nanoparticles using Gloriosa superba L. extract and their antibacterial activity. Journal of Taibah University for Science. 2015;9(1):7-12.

55. Sivaraj R, Rahman PK, Rajiv P, Salam HA, Venckatesh R. Biogenic copper oxide nanoparticles synthesis using Tabernaemontana divaricate leaf extract and its antibacterial activity against urinary tract pathogen. Spectrochimica Acta Part A: Molecular and Biomolecular Spectroscopy. 2014;133:178-181.

56. Sankar R, Manikandan P, Malarvizhi V, Fathima T, Shivashangari KS, Ravikumar V. Green synthesis of colloidal copper oxide nanoparticles using Carica papaya and its application in photocatalytic dye degradation. Spectrochimica Acta Part A: Molecular and Biomolecular Spectroscopy. 2014;121(2014):746-750.

57. Sankar R, Maheswari R, Karthik S, Shivashangari KS, Ravikumar $\mathrm{V}$. Anticancer activity of Ficus religiosa engineered copper oxide nanoparticles. Materials Science and Engineering: C. 2014;44:234-239.

58. Gopalakrishnan K, Ramesh C, Ragunathan V, Thamilselvan M. Antibacterial activity of $\mathrm{Cu} 2 \mathrm{O}$ nanoparticles on $\mathrm{E}$. coli synthesized from tridax procumbens leaf extract and surface coating with polyaniline. Digest Journal of Nanomaterials and Biostructures. 2012;7(2):833-839. 
59. Li P, Lv W, Ai S. Green and gentle synthesis of $\mathrm{Cu} 2 \mathrm{O}$ nanoparticles using lignin as reducing and capping reagent with antibacterial properties. Journal of Experimental Nanoscience. 2016;11(1):18-27.

60. Abdelmonem AM, Amin RM. Rapid Green Synthesis of Metal Nanoparticles using Pomegranate Polyphenols. International Journal of Sciences: Basic and Applied Research (IJSBAR). 2014;15(1):57-65.

61. Ahmed S, Ahmad M, Swami BL, Ikram S. A review on plants extract mediated synthesis of silver nanoparticles for antimicrobial applications: A green expertise. Journal of Advanced Research . 2016;7(1):17-28.

62. Machado S, Pinto SL, Grosso JP, Nouws HPA, Albergaria JT, Delerue-Matos C. Green production of zero-valent iron nanoparticles using tree leaf extracts. Science of the Total Environment. 2013;445-446:1-8.

63. Nadagouda MN, Iyanna N, Lalley J, Han C, Dionysiou DD, Varma RS. Synthesis of Silver and Gold Nanoparticles Using Antioxidants from Blackberry, Blueberry, Pomegranate, and Turmeric Extracts. ACS Sustainable Chemistry \& Engineering. 2014;2(7):1717-1723.

64. Iravani S. Green synthesis of metal nanoparticles using plants. Green Chemistry. 2011;13(10):2638-2650.
65. Niu Z, Li Y. Removal and Utilization of Capping Agents in Nanocatalysis. Chemistry of Materials. 2013;26(1):72-83.

66. Park SJ, Jang YS. Preparation and characterization of activated carbon fibers supported with silver metal for antibacterial behavior. Journal of Colloid and Interface Science. 2003;261(2):238-243.

67. Park HS, Koduru JR, Choo KH, Lee B. Activated carbons impregnated with iron oxide nanoparticles for enhanced removal of bisphenol A and natural organic matter. Journal of Hazardous Materials. 2015;286:315-324.

68. Kumar B, Smita K, Cumbal L, Debut A, Angulo Y. Biofabrication of copper oxide nanoparticles using Andean blackberry (Rubus glaucus Benth.) fruit and leaf. Journal of Saudi Chemical Society. 2017;21(Suppl 1):S475-S480.

69. Jurenka J. Therapeutic Applications of Pomegranate (Punica granatum L.): A Review. Alternative Medicine Review. 2008;13(2):128-144.

70. Tseng HH, Wey MY. Effects of acid treatments of activated carbon on its physiochemical structure as a support for copper oxide in DeSO2 reaction catalysts. Chemosphere. 2006;62(5):756-766.

71. Shirmardi M, Alavi N, Lima EC, Takdastan A, Mahvi AH, Babaei AA. Removal of atrazine as an organic micro-pollutant from aqueous solutions: a comparative study. Process Safety and Environmental Protection. 2016;103(Pt A):23-35. 